\title{
STRATIGRAPHY OF ALLUVIAL FILLS AND PHASES OF THE HOLOCENE FLOODS IN THE LOWER WISŁOK RIVER VALLEY, SE POLAND
}

\author{
PIOTR GĘBICA \\ University of Information Technology and Management in Rzeszów, \\ Department of Geography, ul. Sucharskiego 2, 35-225 Rzeszów, Poland \\ Email: piotrgebica@wp.pl
}

\begin{abstract}
Stratigraphy of alluvia and chronology of the Holocene flood events were studied on the basis of 50 radiocarbon dates as well as sedimentological and palynological analyses made on 20 depositional sequences of sediments in the lower section of the Wisłok River valley. These sites evidence the occurrence within the 4-5 $\mathrm{m}$ and 6-7 $\mathrm{m}$ high levels of the floodplain of separate alluvial fills and palaeochannel systems, recording phases of increased Wisłok activity and frequent floods dated at: the Alleröd-Younger Dryas Phase, 9,900-9,600 BP, 8,500-8,000 BP, 6,600$6,100 \mathrm{BP}, 5,400-5,000 \mathrm{BP}, 4,400-4,000 \mathrm{BP}, 2,100-1,700 \mathrm{BP}$, as well as the $11-13^{\text {th }}$ centuries AD and the middle of the $18^{\text {th }}$ century AD. These periods are in accordance with the phases documented earlier within the Upper Vistula River drainage basin, particularly in the for-mountainous section of the Wisłoka River valley, Vistula River valley downstream of Kraków , as well as in the Lower San River valley.
\end{abstract}

Key words: stratigraphy, alluvia, flood phases, Holocene, Wisłok River, SE Poland

\section{STUDY AREA}

The study of floodplain alluvium stratigraphy was concentrated in the east-west elongated erosional trough called by Starkel (1972) the Fore-Carpathian Trough. From the south and the north, the trough is bordered with plateau slopes (Fig. 1). The trough, eroded in Miocene clays as deeply as $11-13 \mathrm{~m}$, is filled with alluvium of the Vistulian (Weichselian) terrace and the Holocene floodplain. The trough is used by the Wisłok River, which flows along its northern margin below the Vistulian terrace (rising 8-12 m above river level), duned in the upper part and undercut in many places by palaeochannels (Gębica and Superson, 2003).

The Holocene floodplain between towns of Rzeszów and Lańcut stands 6-7 m above river level and is $4-6 \mathrm{~km}$ wide. The current riverbed of the Wisłok River is situated in the northern margin of the alluvial fan formed by this terrace. Several palaeochannels, cut off and abandoned owing to avulsion of the Wisłok River and its tributary, Czarna River, are situated on this fan surface. The very curved and partly filled with water, narrow (20-30 m wide) oxbow-lakes system of the Wisłok River, cut off and abandoned due to avulsion after the flood in the middle of the $18^{\text {th }}$ century (Strzelecka, 1958), is the best visible element of the valley landscape. The northern valley trough formed after the avulsion of the Wisłok River to the north and became filled with sands during floods. This plain was subsequently eroded and, simultaneously, aggraded by overbank sediments during floods. Currently, it stands 


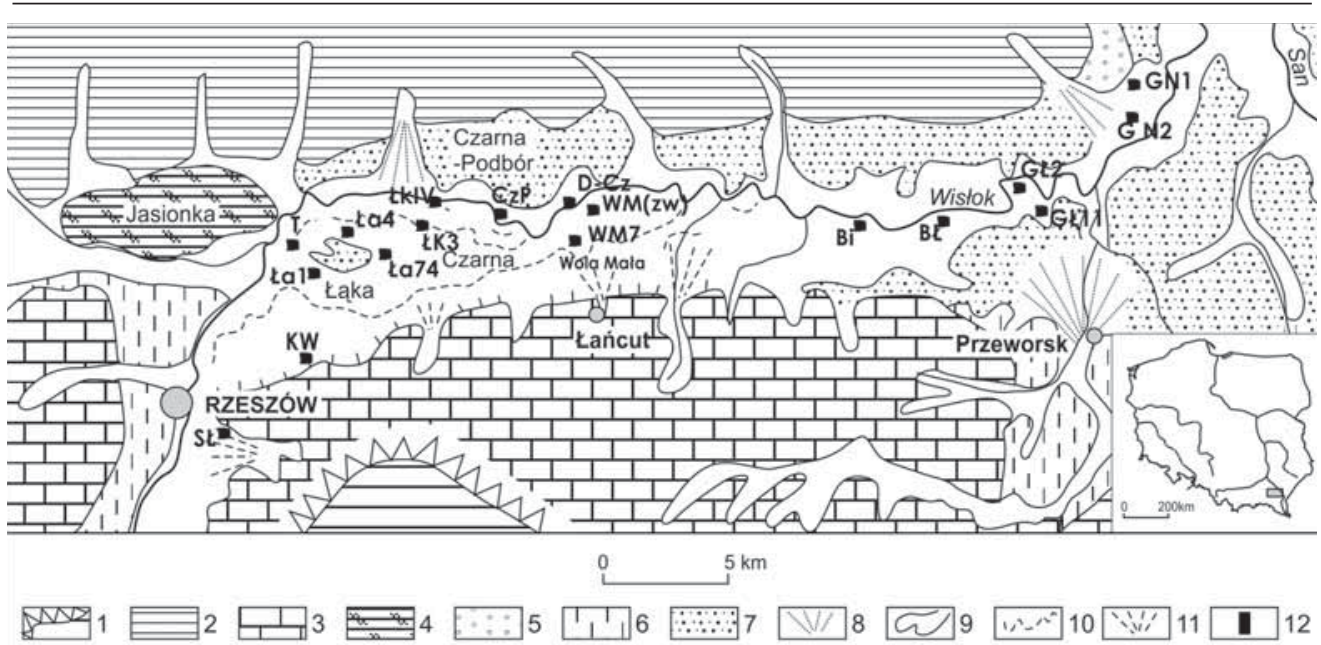

Figure 1. The lower Wisłok River valley and study sites of the Holocene alluvia with radiocarbon dates cited in this paper (elaborated by P. Gębica)

1 - Dynów Foothills escarpment, 2 - Kolbuszowa Plateau, 3 - Kańczuga Loess Plateau; Sanian 2 (Elsterian 2) Glaciation: 4 - fluvioglacial plain; Wartanian (Saalian 2) Glaciation: 5 - river terrace (13-18 $\mathrm{m}$ high); Vistulian (Weichselian) terraces and fans: 6 - loess terrace (15-20-m high), 7 - sandy terrace (8-12-m high), duned at the top, 8 - alluvial fans, 9 - denudational and erosional valleys; Late Vistulian and Holocene: 10 - floodplain and systems of palaeochannels, 11 - alluvial fans; 12 - sites of the Holocene sediments with radiocarbon and OSL dates. List of sites: SŁ - Słocina (Starkel, 1960; Starkel et al., 1999), KW - Krasne-Wólka (Gębica, 2004), Ła1 - Łąka 1 (Gębica, 2004), Ła4 - Łąka 4 (Gębica et al., 2002), T - Terliczka (Gębica and Mitura, 2005), Ła 74 - Łąka archeological site No. 74 (Gębica et al., 2010), ŁkIV - Łukawiec IV (Gębica and Superson, 2003), Łk3 - Łukawiec 3 (Gębica and Superson, 2003), CzP Czarna Podbór (Gębica, 2004), D-Cz - Dąbrówki-Czarna, WM (żw) - Wola Mała (gravel pit) (Gębica et al., 2009a), WM7 - Wola Mała archeological site No. 7 (Gębica et al., 2010), Bi - Białobrzegi, BŁ - Budy Łańcuckie, GŁ2 - Gniewczyna Łańcucka 2, GŁ11 - Gniewczyna Łańcucka 11, GN1 - Grodzisko Nowe 1 (Wójcik et al., 1999), GN2 - Grodzisko Nowe (Dolne) 2 (Gębica et al., 2008)

3-5 $\mathrm{m}$ above river level and is flooded during the yearly overflows. During floods, the overflowing water probably used the abandoned Stary Wisłok riverbed, thus preserving it from filling up. Subsequent floods produced a natural levee along the current riverbed, which has hindered the access of flood water to the Stary Wisłok palaeomeander system. For this reason, during the flood in 1934, water did not reach this palaeochannel system, flooding the lower parts of the 6-7 m high terrace near Łaka village (Lewakowski, 1935; Starkel, 1960). The sandy erosional remnants of the Vistulian terrace situated within the floodplain, rise 1-3 $\mathrm{m}$ above it. On the northern side of the erosional remnant in Łąka village, flatbottomed flood basins without cut-off channels are situated. They are filled with peat sediments of the Late Glacial and the Early
Holocene (Gębica et al., 2002, 2010). In turn, the Late Glacial palaeochannels cover the peaty, southern valley trough (Gębica, 2004).

Between towns of Łańcut and Przeworsk, the floodplain is $2.5-3.5 \mathrm{~km}$ wide and cut as deep as $6-7 \mathrm{~m}$. The lower floodplain level, 4-5 m high, is $0.5-1.0 \mathrm{~km}$ wide and becomes flooded during overflows every year. The floodplain was totally inundated during the flood in May 2010. During this flood, the water covered the lower fragments of the 6-7 m high terrace. Downstream of Przeworsk, the Wisłok River leaves the Fore-Carpathian Trough and flows toward the north-east, along the margins of the Vistulian terrace-fan, turning farther to the north, towards the San River valley. In this part, the Holocene plain is $2.0-2.5 \mathrm{~km}$ wide and is composed of 
a system of terraces rising at 4-5 m, 6-7 m (with a system of curved and narrow palaeochannels), and 8-9 m, with large palaeomeanders undercutting the Vistulian terrace. These palaeochannels were dated near Grodzisko Nowe (Dolne) village to the Late Vistulian (Wójcik et al., 1999; Gębica et al., 2008). They formed in the same time when the large palaeo-meanders of the San River developed (Szumański, 1983, 1986).

\section{PREVIOUS RESEARCH}

The presence of Holocene alluvium was suggested for the first time during the preparation of the Atlas Geologiczny Galicji (The Geological Atlas of Galicia; Friedberg, 1903). Ludera (1930) described the fossil Holocene flora at the Rzeszów and Wola Dalsza (near Lańcut) sites. In the second part of the 1950s, Starkel $(1958,1960)$ studied the floodplain sediments of the Wisłok River valley. On the basis of outcrops and boreholes situated on both sides of the Wisłok riverbed (sequences at the Drabinianka, Staromieście and Słocina sites), he distinguished several cuts and alluvial fills representing various phases of the Late Glacial and the Holocene. The depositional sequence of an alluvial fan at the Słocina site, containing organic sediments interbedded with the Wisłok River alluvium, indicated that the series of overbank (flood) sediments at the right bank of the Wisłok River represents the entire period of the last 10,000 years (Starkel, 1960). Neolithic artifacts found by J. Janowski at the depths of $5 \mathrm{~m}$ and $7 \mathrm{~m}$ confirmed a young Holocene (Subatlantic) age of the overbank alluvium, which overlay channel silts and sands of the Wisłok River at the Staromieście site (Starkel, 1960).

My studies conducted in the ForeCarpathian Trough, in the vicinity of Łąka and Łukawiec villages, proved the occurrence of several erosional valley troughs developed due to frequent avulsions of the Wisłok River. They incise the pleniglacial sediments and are filled with alluvium at- tributed to the Late Vistulian, the Younger Dryas - Holocene transition, as well as the Atlantic period (Gębica et al., 2002; Gębica and Superson, 2003; Gębica, 2004). The system of the Stary Wisłok palaeochannels, cut off and abandoned owing to the flood in the middle of the $18^{\text {th }}$ century, is older than the current (northern) Wisłok riverbed (Strzelecka, 1958). In the area of Grodzisko Nowe (Dolne) village (at the mouth of the Wisłok River to the San River), the Vistulian terrace is undercut by the Wisłok palaeochannel dated at 9,530 $\pm 240 \mathrm{BP}$, thus attributed to the Preboreal Phase. Unpublished results of pollen analysis made by K. Szczepanek indicate that the palaeochannel is filled with Late Glacial organic sediments (Wójcik et al., 1999; Wójcik and Malata, 2004). In the neighbouring Late Glacial palaeochannel of the Wisłok River, silts and sands of the Younger Dryas (bottom dates: 10,450 and $11,670 \mathrm{BP}$ ), are overlain by a peat layer attributed to the end of the Atlantic Phase and Subboreal Phase (dates: 5,400 and 3,000 BP). This peat layer was covered by flood alluvium of the Subatlantic Phase (date 1,780 BP). The stages of palaeochannel filling were connected with climate changes and phases of the colonization of the Grodzisko Nowe (Dolne) archaeological site (Czopek, 2007; Gębica et al., 2008).

Archaeological research works performed at the place of projected A-4 highway enabled OSL dating of ,old” clayeysilty overbank alluvia at the Terliczka site (west of the Lakka site) to 6,470 BP (sample from a depth of $0.75 \mathrm{~m}$ ) and 9,400 BP (sample from a depth of $1.25 \mathrm{~m}$ ). The Late Palaeolithic and Mesolithic flint artifacts were found by P. Mitura in overbank sediments (Gębica and Mitura, 2005).

\section{RESEARCH STRATEGY AND STUDY METHODS}

In the framework of the scientific project "Stratigraphy of alluvia and phases of the Holocene floods within the drainage basins of the San River and the upper 
Dnister River (based on sedimentological, dendrochronological and radiocarbon methods)", granted by the Polish Committee for Scientific Research (KBN) and realized in 2006-2009, the study area was enlarged by including new sites situated between Łańcut town and the Wisłok outlet to the San River (Fig. 1). The outcrop in the gravel pit at Wola Mała village near Łańcut evidenced channel alluvia bearing older tree trunks dated at 11,400 and the younger ones dated at 11,000-10,800 BP, and covered by sands with plant detritus (dated at 9,800 BP) as well as peat filling the cut-off channel dated at 9,600 BP. Within the clayey overbank sediments, at a depth of $2.0 \mathrm{~m}$, a palaeosol (dated at 8,800-8,700 BP) attributed to the Boreal Phase was found (Gębica et al., 2009a; Fig. 2). Boreholes drilled along the transect between the gravel pit at Wola Mała and the palaeochannel system of the Stary Wisłok, proved the occurrence of alluvial fills and palaeochannels of the Preboreal (10,100-9,500 BP), Boreal (9,200-9,000BP) and Atlantic phases $(8,000 \mathrm{BP})$. Fills of the channel alluvia overlain by sediments of the natural levee of the Stary Wisłok River are attributed to the Subatlantic Phase (Gębica et al., 2009a) (Fig. 2).

In 2006, between the towns of Łańcut and Przeworsk, depositional sequences of palaeochannel sediments were exposed at
Dąbrówki village (at the boundary with Czarna Łańcucka village), subfossil tree trunks were found at Białobrzegi village, and a palaeosol found at Budy Łańcuckie was dated. In 2006-2007, a new site of tree trunks occurring in a gravel pit at Gniewczyna Łańcucka, north of Przeworsk, was investigated. More than 70 wood slices were sampled for dendrochronological analysis at this site. The results of dendrochronological analyses will be presented in a separate paper (Gębica and Krąpiec, in print).

In 2006, along a 2.5-km-long transect connecting the gravel-pit bearing tree trunks with the palaeochannel undercutting the Vistulian terrace at Gniewczyna Łańcucka, 12 boreholes were drilled with the „Geomeres" rig vehicle. Grain size analysis of 80 samples and 9 radiocarbon dates and palynological analyses were conducted for 5 logs. Palynological analyses were made by N. Kalinovyč from the Botany Department of the Lviv State Ivan Franko National University, and K. Szczepanek from the Institute of Botany of the Jagiellonian University in Kraków. Radiocarbon datings of wood fragments and other organic samples were made by A. Pazdur in the Radiocarbon Laboratory of the Silesian University of Technology in Gliwice as well as by N. Kovalyukh in the Radiocarbon Laboratory of the Ukrainian Academy of Sciences in Kiev.

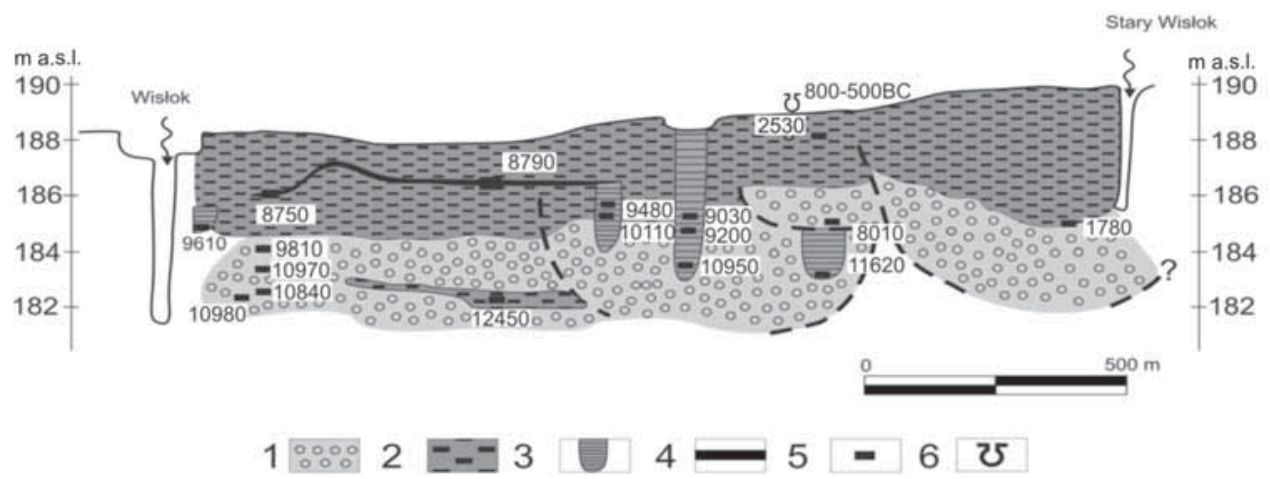

Figure 2. A general scheme of alluvial fills and their radiocarbon ages in the 6-7 m high Wisłok River floodplain (Wola Mała north of Łańcut town; after Gębica et al., 2009a)

1 - channel facies, 2 - overbank facies, 3 - palaeochannel fill facies, 4 - palaeosol, 5 - radiocarbon dates (yrs BP), 6 - Tarnobrzeg Lusatian Culture site 
In total, from 5 borehole logs and 3 outcrops on the Wisłok River, 18 radiocarbon dates (not yet published) were obtained (Table 1). In 2008-2009, owing to archaeological studies conducted at the Ląka, Wola Mała, Białobrzegi and Gorliczyna sites, several new depositional sequences were described, as well as 10 new radiocarbon datings, grain size and palynological analyses were made. These radiocarbon datings, sponsored by the Foundation of Rzeszów Archaeological Center, were made by M. Krąpiec in the Laboratory of Absolute Dating in Skała near Kraków (Gębica et al., 2010).

Analysis of granulometric composition, using the laser granulometer Analysette 22 (Fritsch) and the sieve method, was performed by D. Płoskonka from the Department of Geomorphology and Hydrology of Mountains and Uplands, Institute of Ge- ography and Spatial Organization, Polish Academy of Sciences in Kraków. The results are displayed on diagrams presenting grain size indices of Folk and Ward (1957). The content of organic matter (humus) was analysed in 14 samples.

\section{DESCRIPTION OF THE SITES AND RESULTS OF LABORATORY ANALYSIS}

\section{ŁĄKA, ARCHAEOLOGICAL SITE NO 74}

The artificial outcrop of alluvia was situated on the eastern side of the erosional remnant of the Vistulian terrace in Ląka village (Fig. 1), in the vicinity of the archaeological site no 74, studied in 2009 by Renata Zych. Description of depositional sequence and the results of palynological analysis and radiocarbon datings were presented in

Table 1. Radiocarbon conventional dates and calibrated ages of the alluvial sites in the lower Wisłok River valley cited in this paper (elaborated by P. Gębica)

\begin{tabular}{rllllll}
\hline No. & Site, profile number & Depth $(\mathrm{m})$ & $\begin{array}{l}\text { Type of } \\
\text { material }\end{array}$ & $\begin{array}{l}\text { Laboratory } \\
\text { No }\end{array}$ & $\begin{array}{l}\text { Radiocarbon } \\
\text { Age BP }\end{array}$ & $\begin{array}{l}\text { Calibrated Age } \\
\text { BC/AD }\end{array}$ \\
\hline 1 & Czarna Podbór & $2,60-2,65$ & $\begin{array}{l}\text { fragment of } \\
\text { wood }\end{array}$ & Gd-12403 & $5430 \pm 110$ & \\
& & & & & \\
2 & Dąbrówki-Czarna Łańcucka DbA/1 & $2,70-2,72$ & peat & Gd-12897 & $9500 \pm 110$ & $9250-8550 \mathrm{BC}$ \\
3 & Dąbrówki-Czarna Łańcucka DbA/2 & $3,05-3,07$ & peat & Gd-12898 & $9690 \pm 110$ & $9350-8750 \mathrm{BC}$ \\
4 & Dąbrówki-Czarna Łańcucka DbA/3 & $3,25-3,30$ & organic clay & Gd-15962 & $9780 \pm 110$ & $9700-8800 \mathrm{BC}$ \\
5 & Dąbrówki-Czarna Łańcucka DbA/4 & $2,70-2,75$ & trunk & Ki13391 & $10100 \pm 80$ & $10400-9300 \mathrm{BC}$ \\
6 & Dąbrówki-Czarna Łańcucka CzDb 3/11 & $2,15-2,17$ & organic silt & Ki15330 & $6210 \pm 110$ & $5500-4850 \mathrm{BC}$ \\
7 & Białobrzegi A/1 & 6,30 & trunk & Ki-13397 & $9890 \pm 80$ & $9700-9200 \mathrm{BC}$ \\
8 & Białobrzegi B/1 & 5,0 & trunk & Ki-13399 & $9630 \pm 60$ & $9230-8790 \mathrm{BC}$ \\
9 & Białobrzegi A/2 & 3,70 & trunk & Ki-13400 & $8110 \pm 50$ & $7200-7030 \mathrm{BC}$ \\
10 & Budy Łańcuckie 1/1 & $2,1-2,2$ & paleosol & Ki-13364 & $6680 \pm 60$ & $5670-5480 \mathrm{BC}$ \\
11 & Gniewczyna Łańcucka 2 GNC-2/4a & $5,80-5,82$ & organic clay & Gd-16412 & $1120 \pm 110$ & $660-1060 \mathrm{AD}$ \\
12 & Gniewczyna Łańcucka 2 GNC-2/6 & $6,05-6,10$ & organic clay & Gd-16415 & $1225 \pm 105$ & $640-1020 \mathrm{AD}$ \\
13 & Gniewczyna Łańcucka 8 & $2,40-2,45$ & paleosol & Gd-15983 & $6590 \pm 140$ & $5800-5200 \mathrm{BC}$ \\
14 & Gniewczyna Łańcucka 11 GNC-11/3 & $0,75-0,80$ & organic silt & Gd-12910 & $3970 \pm 60$ & $2700-2250 \mathrm{BC}$ \\
15 & GNC11/5 & $1,15-1,20$ & peat & Gd-12911 & $9480 \pm 75$ & $9150-8600 \mathrm{BC}$ \\
16 & GNC 11/6 & $1,45-1,50$ & organic silt & Gd-15977 & $9680 \pm 150$ & $9700-8600 \mathrm{BC}$ \\
17 & GNC 11/8 & $1,75-1,80$ & organic silt & Gd-30128 & $9860 \pm 200$ & $10100-8700 \mathrm{BC}$ \\
18 & GNC 11/6,5 & $1,63-1,65$ & organic silt & Gd-15981 & $10210 \pm 160$ & $10700-9300 \mathrm{BC}$ \\
\hline
\end{tabular}


the "Materiały i Sprawozdania Rzeszowskiego Ośrodka Archeologicznego" (Gębica et al., 2010). Radiocarbon dating results were supplemented with granulometric diagram and grain size indices presented in Fig. 3.

Upon the channel sands $(\mathrm{Mz}=1.54 \Phi)$, in the interval of $2.0-2.3 \mathrm{~m}$, silts with an admixture of organic material and peat layer occur. At a depth of $2.0 \mathrm{~m}$, they are overlain by steelgray clays $(\mathrm{Mz}=7.74 \Phi), 0.2 \mathrm{~m}$ thick, deposited in the flood basin. The clays are covered by clayey silts $(\mathrm{Mz}=6.62 \Phi)$, passing upwards into silts $(\mathrm{Mz}=6.2 \Phi)$. At a depth of $0.80-1.35 \mathrm{~m}$, a layer of silts with admixture of sand fraction (ranging 20\%) of average diameter $\mathrm{Mz}=5.56 \Phi$ occurs, which evidences flood deposition of coarser material in the flood basin. Palynological analyses made by K. Szczepanek indicate that organic deposition on the floodplain commenced at the beginning of the Holocene and finished in the Boreal Phase. Radiocarbon datings of a silt sample bearing organic material, taken at a depth of $2.23 \mathrm{~m}(9,230 \pm 90 \mathrm{BP}, \mathrm{MKL}-206)$, as well as of peat samples taken at the depths of $2.12 \mathrm{~m}(8,380 \pm 70 \mathrm{BP}, \mathrm{MKL}-205)$ and $2.04 \mathrm{~m}$ (7,810 $\pm 60 \mathrm{BP}, \mathrm{MKL}-204)$ indicate deposition of silty-organic sediments in the Boreal Phase and at the beginning of the Atlantic Phase. Thus, clays overlying the dated peat horizon probably represent the phase of flood deposition during 8,000-7,500 BP (Starkel, 2001).

\section{DĄBRÓWKI-CZARNA ŁAŃCUCKA SITE}

The outcrop of alluvium was dug in 2006 within a meander of the Wisłok River, at the boundary between Czarna Lańcucka and Dąbrówki villages $(5.5 \mathrm{~km}$ north-west of Łańcut town) (Fig. 1). The depositional sequence consists of palaeochannel fills within the floodplain standing $6.5 \mathrm{~m}$ above water table (188 m a.s.l.).

Depositional sequence (from the top):

- $0.0-0.40 \mathrm{~m}-$ silts with sand admixture

- 0.40-0.90 m - dark steel-gray clays

- $\quad 0.90-2.70 \mathrm{~m}-$ silts grading downwards to dark steel-gray lumpy clays

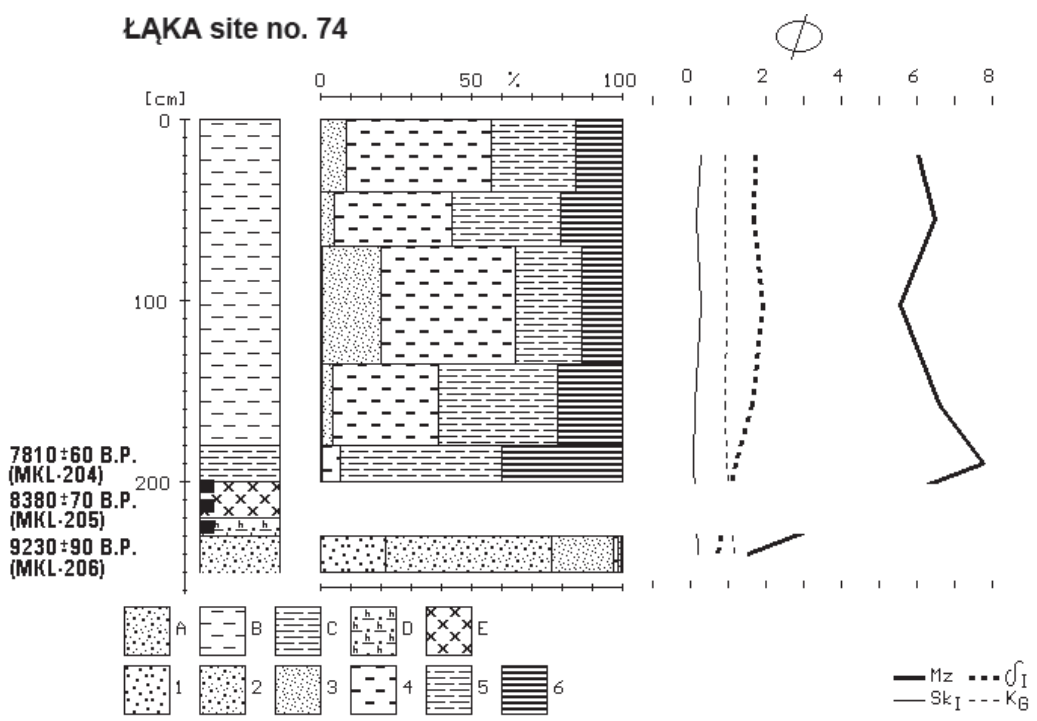

Figure 3. Łąka site no 74. Lithology, grain size indices (after Folk and Ward) and radiocarbon dates (elaborated by D. Płoskonka and P. Gębica)

Sediments: A-sand, B-silt, C-clayey silt, D-organic sandy silt, E-peat. Grain size intervals: 1 - coarse sand ( -1 to $1 \Phi), 2$

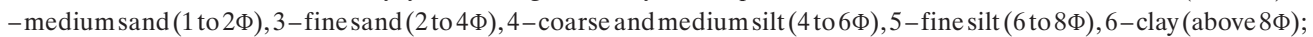
$\mathrm{Mz}$ - mean grain size, $\sigma_{\mathrm{I}}$ - standard deviation, $\mathrm{Sk}_{\mathrm{I}}-$ skewness, $\mathrm{K}_{\mathrm{G}}-$ kurtosis 
- 2.70-3.10 m-black, compacted peat with wood fragments at the top

- 3.10-3.45 m - dark gray clays with occasional organic material, at the bottom light gray and without organic admixture

- 3.45-4.90 m - dark gray clays grading downwards to dark steel-gray clays

- 4.90-6.00 m - silts with sand admixture

- 6.00-6.50 m-silts and gravels.

The wood peat and organic clays occurring under the clays at a depth of $2.70-3.45 \mathrm{~m}$ is a characteristic element of this sequence.

18 samples for palynological analysis were taken from peat and clay in the sections at the depths of $2.70-3.45$ and $4.75-4.80 \mathrm{~m}$. This analysis evidences a large content of tree pollen ranging from $70 \%$ to $90 \%$, with predominance of pine (Pinus sp.), stone pine (Pinus cembra), birch (Betula sp.), spruce (Picea $s p$.), larch (Larix sp.), willow (Salix sp), and occurrence of elm, hazel and lime. It points to deposition of these sediments during the Preboreal Phase. In samples taken at a depth of 3.20-3.40 m, pollen of aquatic plants (e.g., Myriophyllum sp., Nuphar sp., Nymphea sp.) were found, indicating the presence of a water basin. Above this section, pollen of marsh plants (Menyanthes trifoliata, Typha latifolia, Equisetum sp., etc.) and occasional pollen of Sphagnum sp. occur, pointing to overgrowing of the oxbow lake.

Four samples taken from the outcrop were radiocarbon-dated. The sample of clay with an admixture of organic material, taken at a depth of 3.25-3.30 m, was dated to $9,780 \pm 110 \mathrm{BP}(\mathrm{Gd}-15962)$. The sample from a depth of $3.05-3.07 \mathrm{~m}$ was dated to 9,690 110 BP (Gd-12898), while that collected from the top of peat layer at a depth of 2.70-2.72 m was dated at 9,500 $\pm 110 \mathrm{BP}(\mathrm{Gd}-$ 12897). In turn, the date of tree trunk occurring at the top of this peat layer, obtained in the laboratory in Kiev, displays a slightly older age $-10,100 \pm 80 \mathrm{BP}$ (Ki-13391). The results of radiocarbon datings indicate the filling of the palaeochannel during the Preboreal Phase. They are in accordance with the results of palynological analysis, however, the dating of the tree trunk (10,100 BP) suggests that the age of the other three samples (at the bottom of the cut-off channel) could have been slightly rejuvenated.

The radiocarbon date of compacted peat sample taken in 2004 from the gravel pit situated ca. $450 \mathrm{~m}$ east of the DąbrówkiCzarna Łańcucka site is very similar to the above datings and values 9,640 $280 \mathrm{BP}$ (Gd12658). Palynological analysis of this sample shows a pollen spectrum very much alike that described from the Dąbrówki-Czarna Łańcucka site, characterized by the occurrence of tree and shrub pollen (58\%), with the predominance of pine (Pinus sp. $44,5 \%$ ). Pollen of birch (Betula sp. - 3,2\%) and elm (Ulmus sp. - 1,7\%) as well as occasional pollen of oak (Quercus sp.) and hazel (Corylus sp.) are also observed. Among herbaceous plants, grass pollen predominate $(40 \%)$, however, pollen of aquatic plants and plants growing on the lake shore occur as well. The sample is attributed to the Early Holocene. Therefore, the depositional sequence of the Dąbrówki-Czarna Łańcucka site and the sample from the gravel pit represent the Early Holocene system of the Wisłok palaeochannel. Both these sites can be correlated with the similar sequences of the Wisłok palaeochannel fills dated at 10,100-9,500 and 9,600 BP, which are situated at the southern side of the valley in Wola Mała village (Gębica et al., 2009a) (cf. Fig. 2). They prove the Preboreal (10,1009,500 BP) period of riverbed stabilization, connected with peat sedimentation on the wide floodplain situated to the north of the Stary Wisłok palaeochannels.

\section{WOLA MAŁA, ARCHAEOLOGICAL SITE NO 7}

The archaeological site no 7 at Wola Mała village is situated about $1.5 \mathrm{~km}$ to the south of the current Wisłok riverbed. $0,5 \mathrm{~km}$ to the south, the Stary Wisłok palaeochannel, cut-off and abandoned during the flood in the middle of the $18^{\text {th }}$ century (Strzelecka, 1958), is situated (Fig. 1). In 2009, the archaeological study conducted at the site no 7 in Wola Mała village by Monika Hozer and Anna Bajda-Wesołowska resulted in discovering of the remnants of the Tarnobrzeg Lusatian Culture settlement. Borehole Wola 
Mała 6 was drilled in this place in 2007. It drilled cut-off channel peat sediments of the Boreal Phase, which were overlain by channel sands with wood fragments, dated at a depth of $4.35-4.42 \mathrm{~m}$ to $8,010 \pm 50 \mathrm{BP}$ (GdS-575), thus marking the beginning of the Atlantic Phase (Gębica et al., 2009a). In 2009, a 3.7-m-deep trench was dug with mechanic excavator at this archaeological site. The preliminary description of this outcrop sequence, photographic documentation, and the results of three radiocarbon datings were published in the "Materiały i Sprawozdania Rzeszowskiego Ośrodka Archeologicznego" (Gębica et al., 2010). The depositional sequence was sampled for granulometric analysis, whose results are shown together with those of radiocarbon datings in Fig. 4.

In the above mentioned sequence, under recent soil, silts occur to a depth of $1.65 \mathrm{~m}$. These silts are more clayey at the top $(\mathrm{Mz}=6.0-6.6 \Phi)$ and get coarser downward $(\mathrm{Mz}=5.8-6.0 \Phi)$. At a depth of $0.6-0.8 \mathrm{~m}$, they are intercalated by a dark silt-clay horizon $(\mathrm{Mz}=6.1-6.6 \Phi)$ bearing charcoal fragments and resembling a palaeosol. The charcoal fragments were dated at 2,530 $\pm 40 \mathrm{BP}$ (MKL-210), i.e., in accordance with the existence of the Tarnobrzeg Lusatian Cul- ture settlement. In the $1.65-3.00 \mathrm{~m}$ depth interval, sandy silts $(\mathrm{Mz}=4.9-5.4 \Phi)$ and silty sands $(\mathrm{Mz}=3.13 \Phi)$ with wood fragments occur. A wood fragment collected from silts at a depth of $2.06-2.10 \mathrm{~m}$ was dated to $6,130 \pm 60$ BP (MKL-207), while the date of elm trunk buried in sand bars $(\mathrm{Mz}=2.7 \Phi)$ at a depth of $3.6 \mathrm{~m}$ values 7,430 $\pm 60 \mathrm{BP}$ (MKL208). The same age $-7,470 \pm 60 \mathrm{BP}$ (MKL209) was obtained for the second elm trunk found in sands at a depth of 3.40-3.70 m (Gębica et al., 2010).

Therefore, in the former (archival) borehole Wola Mała 6, deposition of cutoff channel sediments during the Boreal Phase was broken by deposition of channel sands at the beginning of the Atlantic Phase (8,010 BP) (Gębica et al., 2009a), being accurately correlated with the end of the phase of frequent floods $(8,500-8,000 \mathrm{BP})$ distinguished by Starkel ed. (1981) and Starkel et al. (1996). After this phase, declined some $8,000-7,800 \mathrm{BP}$, the next intensification of flood deposition at this site took place about 7,500-7,400 BP. The alternation of deposits from sands to silty sands at a depth of $3.0 \mathrm{~m}$ marks the weakening of river activity and growth of overbank deposition. Silt-sandy alluvia, with a wood fragment dated at a depth

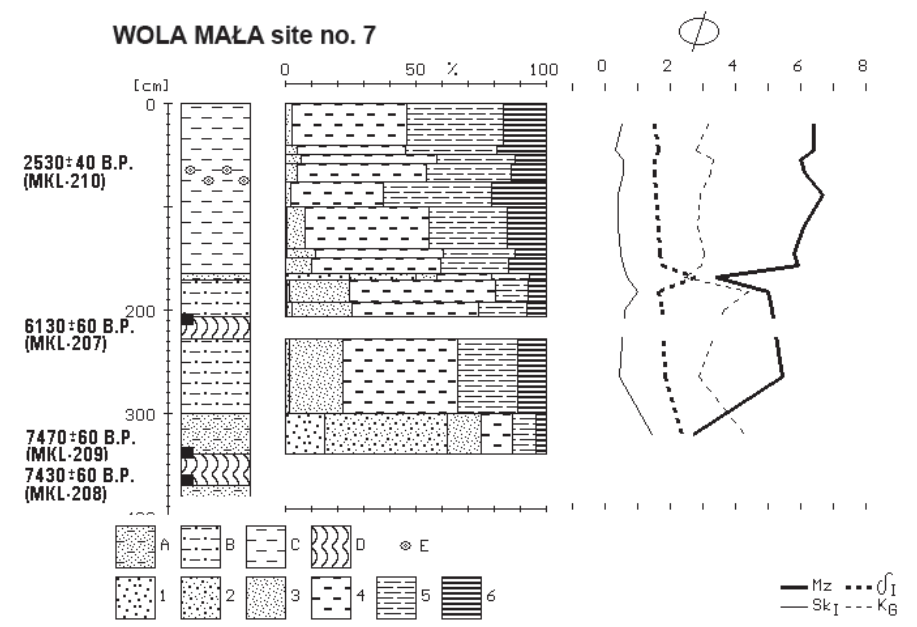

Figure 4. Wola Mała site no 7. Lithology, grain size indices (after Folk and Ward) and stratigraphy of overbank facies (elaborated by D. Płoskonka and P. Gębica)

Sediments: A - silty sand, B - sandy silt, C - silt, D - tree trunk, E - charcoal. For other explanations - see Fig. 3 
of $2.1 \mathrm{~m}$ at $6,130 \mathrm{BP}$, mark the decline of the active phase of overbank (flood) deposition $(6,600-6,000 \mathrm{BP})$ in the sequence (Starkel, 2001). Silty-clayey sediments with an intercalation of palaeosol and charcoal fragments at a depth of $0.6-0.8 \mathrm{~m}$, dated at $2,530 \mathrm{BP}$ (800-520 BC), indicate substantial weakening of floods or break in flood-type deposition. The reason for this could have been deepening of the Wisłok riverbed or its significant removal from the settlement of the Tarnobrzeg Lusatian Culture site.

\section{BIAŁOBRZEGI SITE}

In Białobrzegi village, within the cut of the Wisłok riverbed $(9.5 \mathrm{~km}$ east of the gravel pit in Wola Mała village), a depositional sequence of the 7-m-high terrace with tree trunks was exposed (Figs. 1, 5). Under the 2-m-thick layer of brown alluvial silts, clayey silts $(0.5 \mathrm{~m})$ and bedded silts and sands (levee sediments) reach a depth of $3.5 \mathrm{~m}$. Within the depth interval of 3.5-5.0 m, overbank clayey and fine-grained sands occur. They bear wood fragments, thin branches and trunks at a depth of $3.7-4.1 \mathrm{~m}$. The $5.0-6.3 \mathrm{~m}$ interval is composed of laminated clayey silts and clays with sand admixture (sediments of alluvial fan-delta accumulated in an oxbow lake) bearing wood fragments and other organic material (Fig. 5). In silts, close to the boundary with sands, a tree trunk was buried at a depth of $6.3 \mathrm{~m}$. Sands with gravel admixture of the channel facies underlay silts with this trunk, reaching the water table of the river. Ten samples of silts bearing sands and organic material were taken from the interval of $5.2-6.3 \mathrm{~m}$ for palynological analysis, which, however, evidenced the lack of pollen (det. by K. Szczepanek).

Tree trunks occurring within the sediments were radiocarbon-dated in the laboratory in Kiev. The wood sample from the trunk occurring in silty sands at a depth of $3.7 \mathrm{~m}$ (trunk no. 1) was dated at 8,110 $\pm 50 \mathrm{BP}$ (Ki-13400), thus pointing to the Atlantic Phase. The date of a hornbeam trunk buried in clayey sands $25 \mathrm{~m}$ east of the first trunk at a depth of $5.0 \mathrm{~m}$ (trunk no. 2) values 9,630 $\pm 60 \mathrm{BP}$ (Ki-13399), indicating the

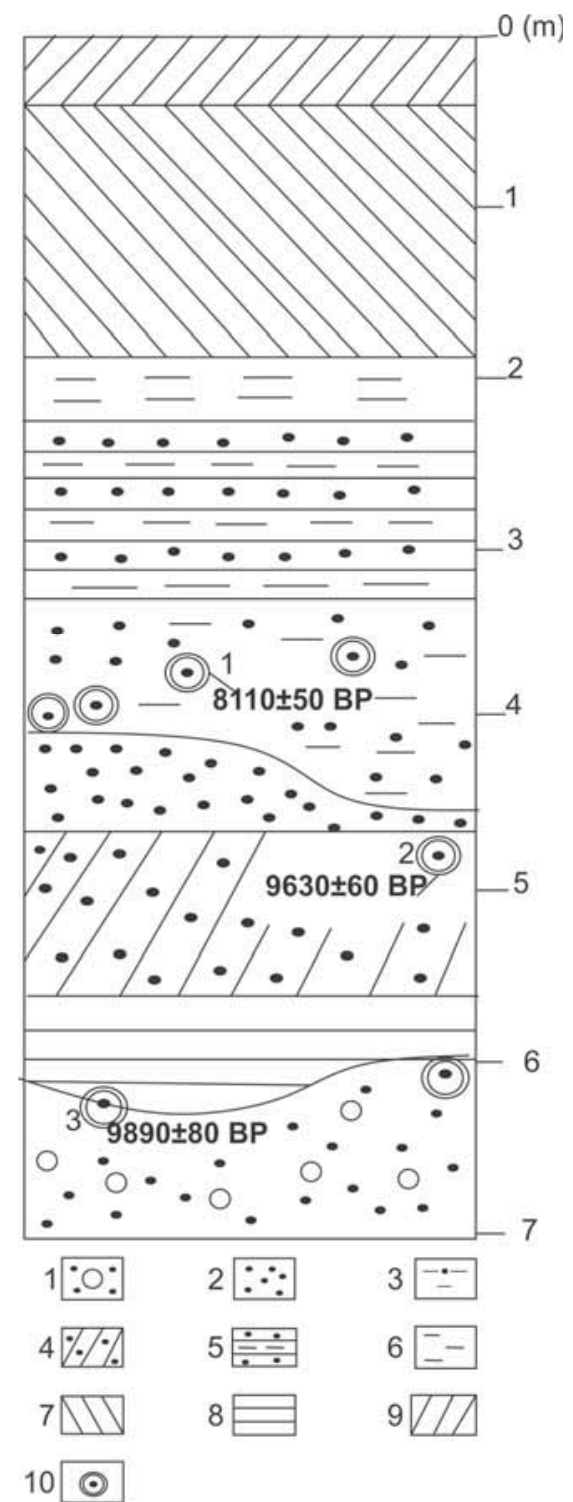

Figure 5. Białobrzegi site. Outcrop of the 7-m-high floodplain. Stratigraphy of palaeochannel fill and overbank facies with subfossil trunks

1 - sand with gravel (channel facies), 2 - sand (point bar subfacies), 3 - silty sand (overbank facies), 4 - fan-delta deposits, 5 - sand interbedded with silt (natural levee deposits), 6 - mud (flood basin deposits), 7 - alluvial fines ("madas"), 8 - palaeochannel fill, 9 - Holocene soil, 10 - subfossil tree trunk and radiocarbon dates (years BP) 
Preboreal Phase. The third (no. 3) trunk buried in silts close to their boundary with sands, at a depth of $6.3 \mathrm{~m}$, was dated at 9,890 \pm 80 BP (Ki-13397).

The Białobrzegi site documents the Early Holocene phase of the Wisłok cut-off channel infilling with fan-delta sediments bearing trees fallen about 9,900 and 9,600 BP. When at the Białobrzegi site the tree trunks were deposited during floods, the accumulation of organic sediments took place $(10,100-$ 9,500 BP) within the cut-off channels at the sites of Dąbrówka-Czarna and Wola Mała. At the beginning of the Atlantic Phase $(8,100 \mathrm{BP})$, the cut-off channel and fan-delta sediments at Białobrzegi was covered with sand bars. This is accurately correlated with the sequence drilled in Wola Mała 6 borehole, in which the organic sediments are overlain by sands of flood deposition, with a trunk dated at 8,010 BP (Gębica et al., 2009a).

\section{BUDY ŁAŃCUCKIE SITE}

The site is situated on the right bank of the Wisłok River, in the floodplain rising $5.5 \mathrm{~m}$ above water table, $3 \mathrm{~km}$ to the east of the above described Białobrzegi site (Fig. 1). The sequence represents deposition of overbank alluvia (with a palaeosol horizon) overlying channel sands. At the top of the sequence, a 1.0-m-thick layer of clayey silt was exposed. The lower part of the sequence, at a depth of 1.0-1.9 m, is composed of finegrained, light yellow sands and olive-grey silts, which represent levee sediments. In the interval of 1.9-2.2 m, dark-brown clayeysilts bearing organic material and resembling a palaeosol occur. They rest upon grey sandy silts of overbank sediments, reaching a depth of $2.6 \mathrm{~m}$. Channel sands occurring below this layer extend to the riverbed level.

Palynological analysis of the palaeosol sampled at a depth of 2.1-2.2 $\mathrm{m}$ indicates the occurrence of pollen of pine, oak, hazel, elm, hornbeam, ash, lime and cereals. The composition of pollen spectrum suggests predomination of deciduous forests, attributed to the Atlantic Phase, and probably indicating cereals cultivation. This sample was dated by radiocarbon method at $6,680 \pm 60 \mathrm{BP}$
(Ki-13364), thus it confirms the Atlantic Phase. The calibrated age of this sample, 5,670-5,480 cal BC (Table 1), corresponds with development of the Neolithic agricultural cultures. It is confirmed by traces of the Neolithic colonization and settlement of the Funnel Beaker Culture found by archaeologists in the area of Budy Lańcuckie village and neighbouring Białobrzegi village (Czopek and Kadrow, 1987; Czopek and Podgórska-Czopek, 1995). This indicates interrelation between the beginning of deposition of overbank sediments at the Budy Łańcuckie site with a phase of frequent floods during 6,600-6,000 BP (Starkel, 2001) and human activity in the Early Neolithic time.

\section{GNIEWCZYNA ŁAŃCUCKA SITE NORTH OF PRZEWORSK TOWN}

\section{STRUCTURE AND AGE OF THE 4-5 M HIGH FLOODPLAIN}

The floodplain in Gniewczyna Łańcucka ( $6 \mathrm{~km}$ to the NNW of Przeworsk town) stands 4-5 $\mathrm{m}$ above the river level (177.5-178.5 $\mathrm{m}$ a.s.l.) and is $500-1,000 \mathrm{~m}$ wide. Several generations of the Late Holocene palaeochannels are here visible: from very large meanders $(\mathrm{r}=390 \mathrm{~m}$, $\mathrm{w}=30-70 \mathrm{~m})$ to small ones $(\mathrm{r}=60 \mathrm{~m}, \mathrm{w}=20-$ $-30 \mathrm{~m})$. The palaeochannels undercut the $6-7 \mathrm{~m}$ high floodplain (179-180 m a.s.l.) (Fig. 6).

Within one of such palaeochannels, characterized by apparent edges but very small curvature radius $(\mathrm{r}=60 \mathrm{~m})$ and channel width ( $\mathrm{w}=20-30 \mathrm{~m})$ and situated $500 \mathrm{~m}$ south of the Wisłok River, several gravel pits are opened, in which numerous tree trunks were excavated.

$40 \mathrm{~m}$ west of the abandoned gravel pit, in which part of the analysed and sampled tree trunks were found, GNC 2 borehole was drilled in the cut-off channel situated within the floodplain, $5 \mathrm{~m}$ high (Figs. 6, 7). At the top part of the borehole log, an artificial clay mound, $3.5 \mathrm{~m}$ thick, occurs. Silts $(\mathrm{Mz}=6.1-7.1 \Phi)$, $1.75 \mathrm{~m}$ thick, form the highest section of the drilled natural depositional sequence. Clayey silts $(\mathrm{Mz}=6.1-7.2 \Phi)$ bearing organic material and representing the cut-off 


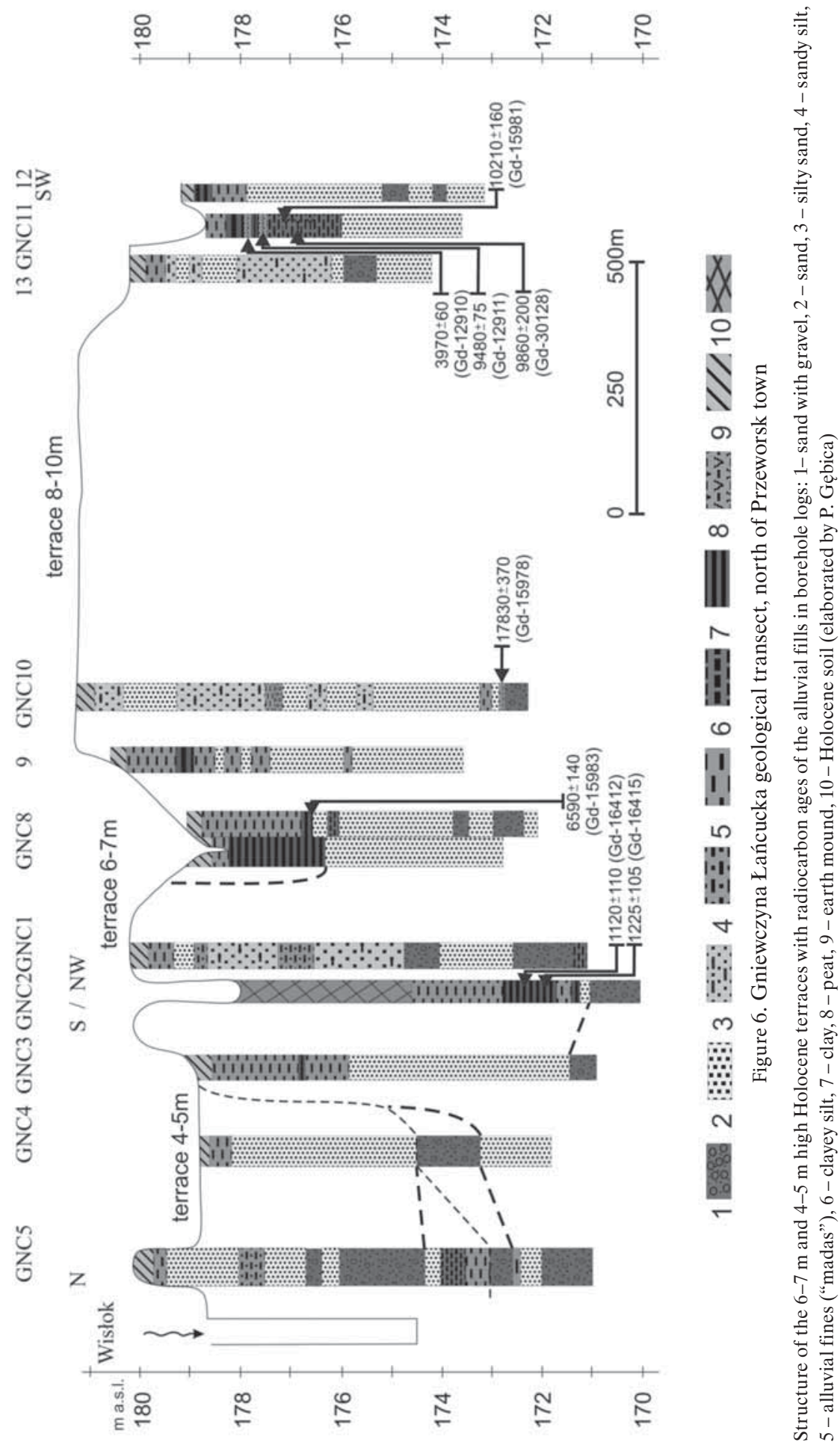




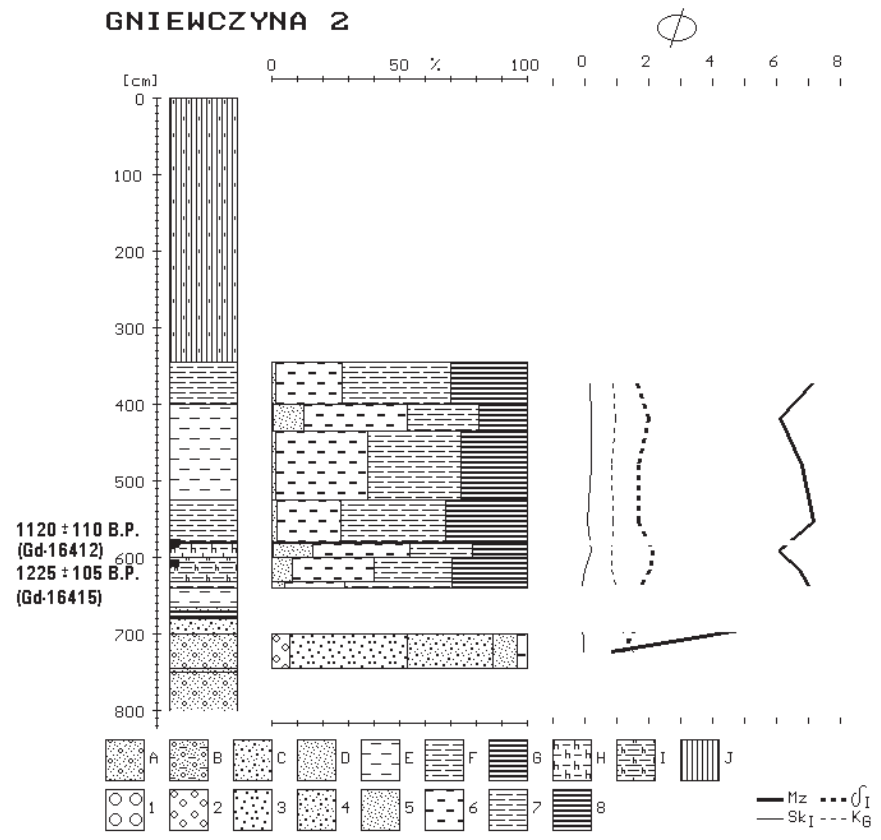

Figure 7. Gniewczyna Łańcucka 2 borehole log. Grain size composition, Folk-Ward's grain size distribution and radiocarbon datings of paleochannel fill GNC2 (elaborated by D. Płoskonka and P.Gębica)

Sediments: A - sand with single gravels, B - silty sand with single gravels, C - medium sand, D - fine sand, E - silt, F - clayey silt, G - clay, H - organic silt, I - organic clayey silt, J - earth mound

Grain size intervals: 1 - coarse gravel (below $-4 \Phi), 2$ - medium and fine gravel ( -4 to $-1 \Phi), 3$ - coarse sand $(-1$ to $1 \Phi)$, 4 - medium sand (1 to $2 \Phi), 5$ - fine sand ( 2 to $4 \Phi), 6$ - coarse and medium silt (4 to $6 \Phi), 7$ - fine silt (6 to $8 \Phi), 8$ - clay (above $8 \Phi$ ); $\mathrm{Mz}$ - mean grain size, $\sigma \mathrm{I}$ - standard deviation, SkI - skewness, $\mathrm{KG}$ - kurtosis

channel sediments occur in the interval of $5.25-6.80 \mathrm{~m}$. They rest upon sands and gravels of the channel facies. A sample of clayey silt with organic material taken at a depth of $5.80-5.82 \mathrm{~m}$ was dated to $1,120 \pm 110 \mathrm{BP}$ (Gd-16412). The radiocarbon date of this sediment sampled at a depth $5.85-5.90 \mathrm{~m}$ is very similar: $1,225 \pm 105 \mathrm{BP}(\mathrm{Gd}-16415)$. These dates indicate that the Wisłok palaeomeander was cut off during a flood in the time span of 1,100-1,200 BP (calibrated age 640-1,060 AD), i.e., in the Early Middle Ages. It is confirmed by dendrochronological analysis and datings of tree trunks buried by sediments of this cut-off channel, among which the youngest generation of 8 trunks was dated to the time span between the end of the $11^{\text {th }}$ century and the beginning of the $13^{\text {th }}$ century (Gębica and Krąpiec, in print).
Boreholes GNC 4 and GNC 5 were drilled $350 \mathrm{~m}$ and $150 \mathrm{~m}$ south of the Wisłok riverbed, respectively. Under the thin cover of silts, in the interval of 0.50-3.35 (4.00) m, fine to medium grained sands, clayey in places, were drilled. In GNC 4 log, they overlay channel sands with gravels reaching the borehole bottom at a depth of $7.0 \mathrm{~m}$ (Fig. 6). In GNC $5 \mathrm{log}$, in turn, silts representing cutoff channel sediments occur in an interval of 6.0-7.0 m. The lowest section of this log (up to its bottom at a depth of $9 \mathrm{~m}$ ) is formed of sands and gravels of the channel facies.

\section{STRUCTURE AND AGE OF THE 6-7 M HIGH FLOODPLAIN}

Borehole GNC 1 was drilled in the 7-mhigh floodplain, undercut from the northern side (GNC 2 borehole log) by an Early Mediae- 
val palaeochannel (Figs. 6, 8). Below silts, silty sands $(\mathrm{Mz}=4.1-4.7 \Phi)$ interbedded with fine and medium grained sands $(\mathrm{Mz}=1.7-2.8 \Phi)$ were drilled at a depth of 0.8-3.6 m. These represent sediments of a natural levee. In the interval of 3.60-5.65 m, sediments of meander bars occur: medium and fine-grained sands $(\mathrm{Mz}=1.15-3.0 \Phi)$ with wood fragments. They rest upon sands with gravels (pebble diameters up to $2.5 \mathrm{~cm})$ of the channel facies $(\mathrm{Mz}=0.73-$ $1.9 \Phi)$, reaching a depth of $8.8 \mathrm{~m}$.

Borehole GNC 8 was drilled $800 \mathrm{~m}$ south of the Wisłok riverbed. The overbank clayey silts $(\mathrm{Mz}=6.7-7.6 \Phi)$ were found below recent soil in the depth interval of $0.55-2.32 \mathrm{~m}$ (Figs. 6, 9). They overlay a 13-cm-thick (2.32-2.45 m) horizon of dark brown clayey silts $(\mathrm{Mz}=5.44 \Phi)$ bearing organic material, which resembles a palaeosol. A deeper interval, $2.45-3.00 \mathrm{~m}$, is represented by silts and sands $(\mathrm{Mz}=2.3-4.2 \Phi)$ of a natural levee. Be- tween $3.0 \mathrm{~m}$ and $7.0 \mathrm{~m}$ depths, vari-grained sands $(\mathrm{Mz}=1.6-1.9 \Phi)$ and sands with gravels of the channel facies occur. The radiocarbon date of a palaeosol at a depth of 2.40-

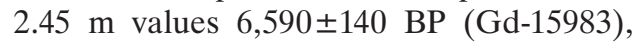
attributing this horizon to the Atlantic Period. A similar sequence of flood (overbank) sediments and age of palaeosol horizon were observed in the outcrop at Budy Łańcuckie.

Borehole GNC 11 was drilled 2,000 m south of the current Wisłok riverbed, within a palaeochannel of curvature radius $\mathrm{r}=230 \mathrm{~m}$ and channel width $\mathrm{w}=30-40 \mathrm{~m}$. This palaeochannel undercuts the Vistulian terrace standing 8-10 $\mathrm{m}$ above water table (Figs. 6, 10). The top part of the sequence of the cut-off channel fills, in total $2.65 \mathrm{~m}$ thick, is composed of clayey silts $(\mathrm{Mz}=6.7-7.0 \Phi)$ $(0.0-0.4 \mathrm{~m})$ and silts with organic material $(0.4-1.65 \mathrm{~m})$. These silts, containing 5.9$-31.0 \%$ of organic material, are inserted

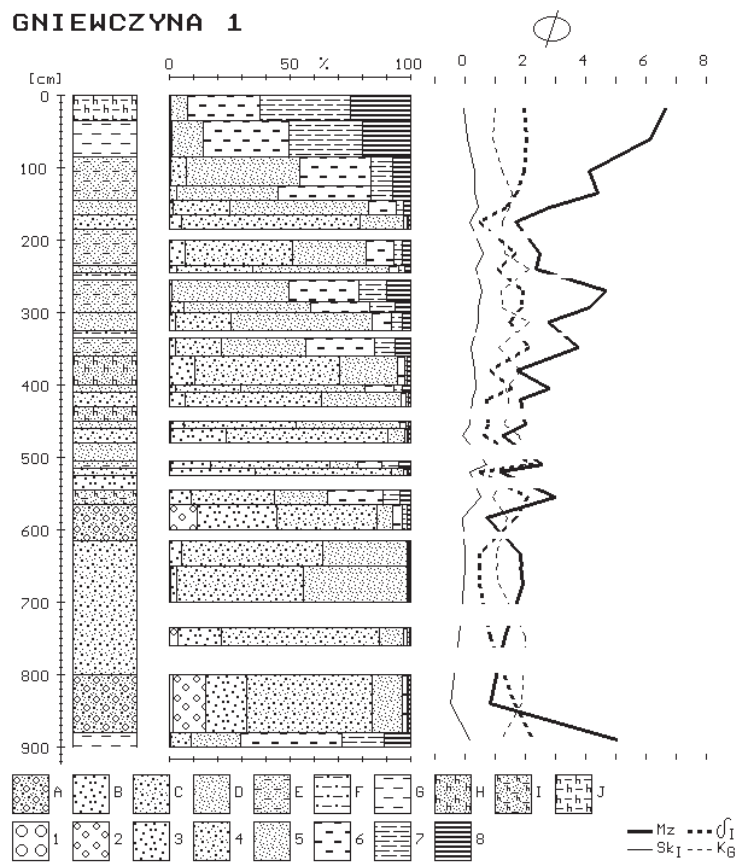

Figure 8. Gniewczyna Łańcucka 1 borehole log. Grain size composition, Folk-Ward's grain size distribution parameters of the levee facies and channel sediments (elaborated by D. Płoskonka and P. Gębica)

Sediments: A - gravel with sand, B - coarse sand, C - medium sand, D - fine sand, E - silty sand, F - sandy silt, G - silt, $\mathrm{H}$ - organic sand, I - organic silty sand, J - Holocene soil. For other explanations - see Fig. 7. 


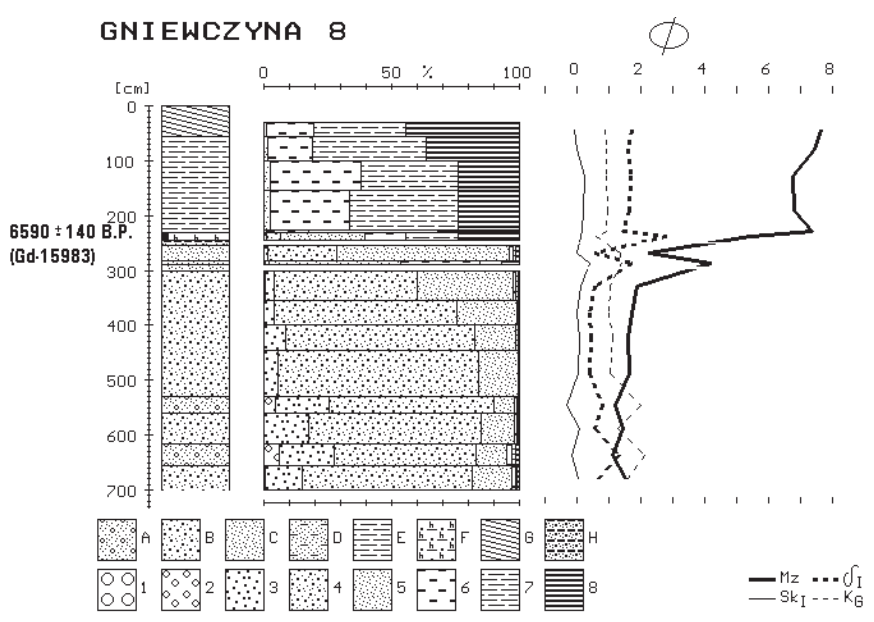

Figure 9. Gniewczyna Łańcucka 8 borehole log. Grain size composition, Folk-Ward's grain size distribution parameters and age of the floodbasin facies and channel sediments

Sediments: A - sand with single gravels, B - coarse and medium sand, C - fine sand, D - silty sand, E - clayey silt, F- organic sandy silt, G - Holocene soil, H - sand interbedded with silt. For other explanations - see Fig. 7 (elaborated by D. Płoskonka and P. Gębica).

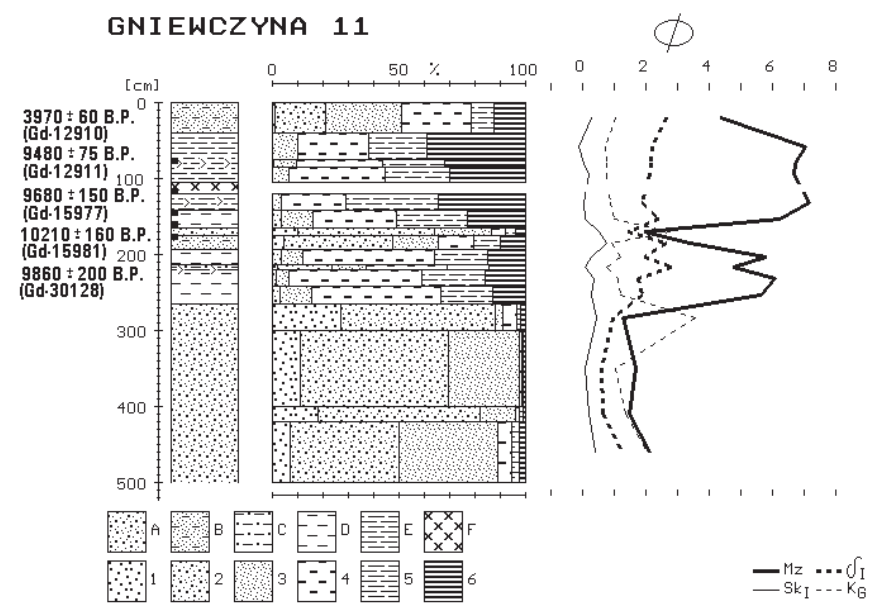

Figure 10. Gniewczyna Łańcucka 11 borehole log. Lithology, grain size indices (after Folk and Ward) and stratigraphy of the Younger Dryas-Preboreal palaeochannel fill (elaborated by D. Płoskonka and P. Gębica)

Sediments: A-medium sand, B - silty sand, C-sandy silt, D - silt, E-clayey silt, F-peat. For other explanations - see Fig. 3.

with a thin horizon of black peat (1.05$-1.20 \mathrm{~m}$ depth) containing $66 \%$ of humus. A layer of sands $(\mathrm{Mz}=1.95-3.4 \Phi)$ in between silt sediments occurs in the interval of $1.65-1.75 \mathrm{~m}$. The lowest silts of the cut-off channel fill sequence $(\mathrm{Mz}=4.8-6.1 \Phi)$ contains an admixture of sand grains (7-35\%) and organic material (2.2-9.0\% of humus). Palynological analysis of the log section of 1.05-1.85 $\mathrm{m}$ evidenced the predomination 
of tree pollen (up to $70 \%$ ) in some samples. Pollen of pine, birch and stone pine (totally $6-21 \%$ ), spruce, larch and elm prevail in the spectrum, which is typical of forest communities characteristic for the Preboreal Phase. Clayey silts with organic material were dated at a depth of $0.75-0.80 \mathrm{~m}$ to $3,970 \pm 60 \mathrm{BP}(\mathrm{Gd}-12910)$, placing this sediment in the Subboreal Phase. The date of a black peat insert at a depth of 1.15-1.20 m values 9,480 $\pm 75 \mathrm{BP}$ (Gd-12911), pointing to the Preboreal Phase. The ages of silts with plant detritus sampled under the peat horizon and determined by radiocarbon datings are: 9,680 $\pm 150 \mathrm{BP}(\mathrm{Gd}-15977)$ at a depth of $1.45-1.50 \mathrm{~m}$, and $10,210 \pm 160 \mathrm{BP}$ (Gd-15981) at a depth of 1.63-1.65 m. These radiocarbon dates confirm the results of palynological analysis, indicating the Younger Dryas-Preboreal age of the lower section of the cut-off channel depositional sequence. They also indicate the depositional gap (hiatus) between the Preboreal and Subboreal phases. Under the silts dated at 10,210 BP, an insert of sands occurs at a depth of $1.65-1.75 \mathrm{~m}$, which was probably deposited by a flood during the Younger Dryas Phase. It overlays silts with organic material, dated at a depth of $1.75-1.80 \mathrm{~m}$ to $9,860 \pm 200 \mathrm{BP}$ (Gd-30128). This last date appears to be rejuvenated. Therefore, both the sand insert and silts in the bottom part of the cutoff channel fills can represent the Younger Dryas Phase.

In summary, in the cross-section of the floodplain at the Gniewczyna Łańcucka site, a palaeochannel filled with alluvium representing the Younger Dryas-Preboreal time can be distinguished. The insert of sands under the sediments dated at 10,200 BP is the sign of a flood, which probably occurred during the Younger Dryas Phase. The beginning of overbank silts and clays deposition during the Atlantic Phase is marked by the date 6,600 BP, obtained from the palaeosol. The watering of the cut-off channel about 4,000 BP is accurately correlated with climate moistening and the end of the phase of frequent floods during 4,400-4,100 BP time span, recorded in the Vistula river valley near Kraków (Kalicki, 1991; Starkel et al., 1996). The youngest fills are composed of alluvia of the 5-m-high floodplain, with a palaeochannel attributed to the Early Middle Ages (1,100-1,200 BP). The trunks buried in the bars of this palaeochannel were dated to the $5-7^{\text {th }}$ centuries AD. The younger series of alluvium was deposited in the period lasting from the $11^{\text {th }}$ till the beginning of the $13^{\text {th }}$ centuries. The period of tree trunks deposition in the $11-13^{\text {th }}$ centuries has not yet been recorded in the Upper Vistula drainage basin (Gębica and Krąpiec, in print).

\section{CHRONOSTRATIGRAPHY OF ALLUVIAL FILLS AND CORRELATION OF THE HOLOCENE FLOOD PHASES}

Intensified floods during the AllerödYounger Dryas Phase are recorded by channel alluvium bearing tree trunks at the Wola Mała site and by sandy fills and inserts in the Wisłok and San palaeochannels (Figs. 11, 12). At the Łukawiec site, the sandy channel alluvium, overlain by clays bearing organic material and dated to 10,150 BP, was deposited probably during the Younger Dryas Phase (Gębica and Superson, 2003). The insert of sands occurring at the bottom of the San River palaeochannel fill at the Kostków site, below the organic sediments dated at $10,100 \mathrm{BP}$, was also deposited by a flood during the Younger Dryas Phase (Gębica et al., 2009b).

The Preboreal Phase (10,100-9,500 BP) is marked by peat accumulation in the system of Wisłok cut-off channels at the sites of Wola Mała, Dąbrówki-Czarna Lańcucka, and Gniewczyna Lańcucka. The date $9,770 \pm 110 \mathrm{BP}$ obtained within the sequence of the Wisłok cut-off channel at the southern side of the erosional remnants at the Laka site also indicates peat accumulation during the Preboreal Phase (Gębica, 2004). These latter datings of peat samples seem to represent the stable periods, during which organic accumulation was possible in the cut-off channels (Gębica and Starkel, 1995; Starkel, 2002). The series of flood sediments bearing tree trunks, attributed to the Preboreal Phase (9,900-9,600 BP), is well evidenced at 


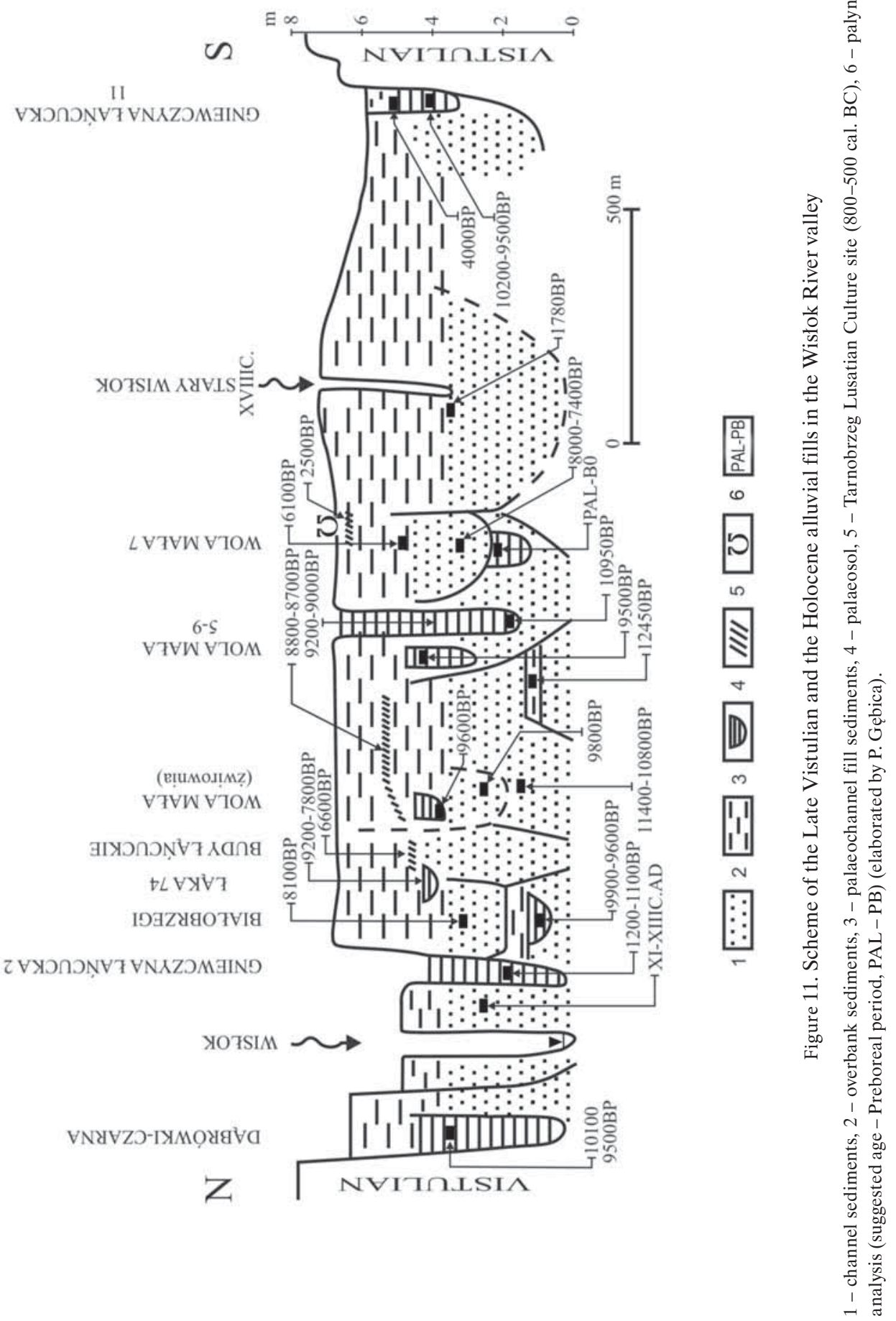




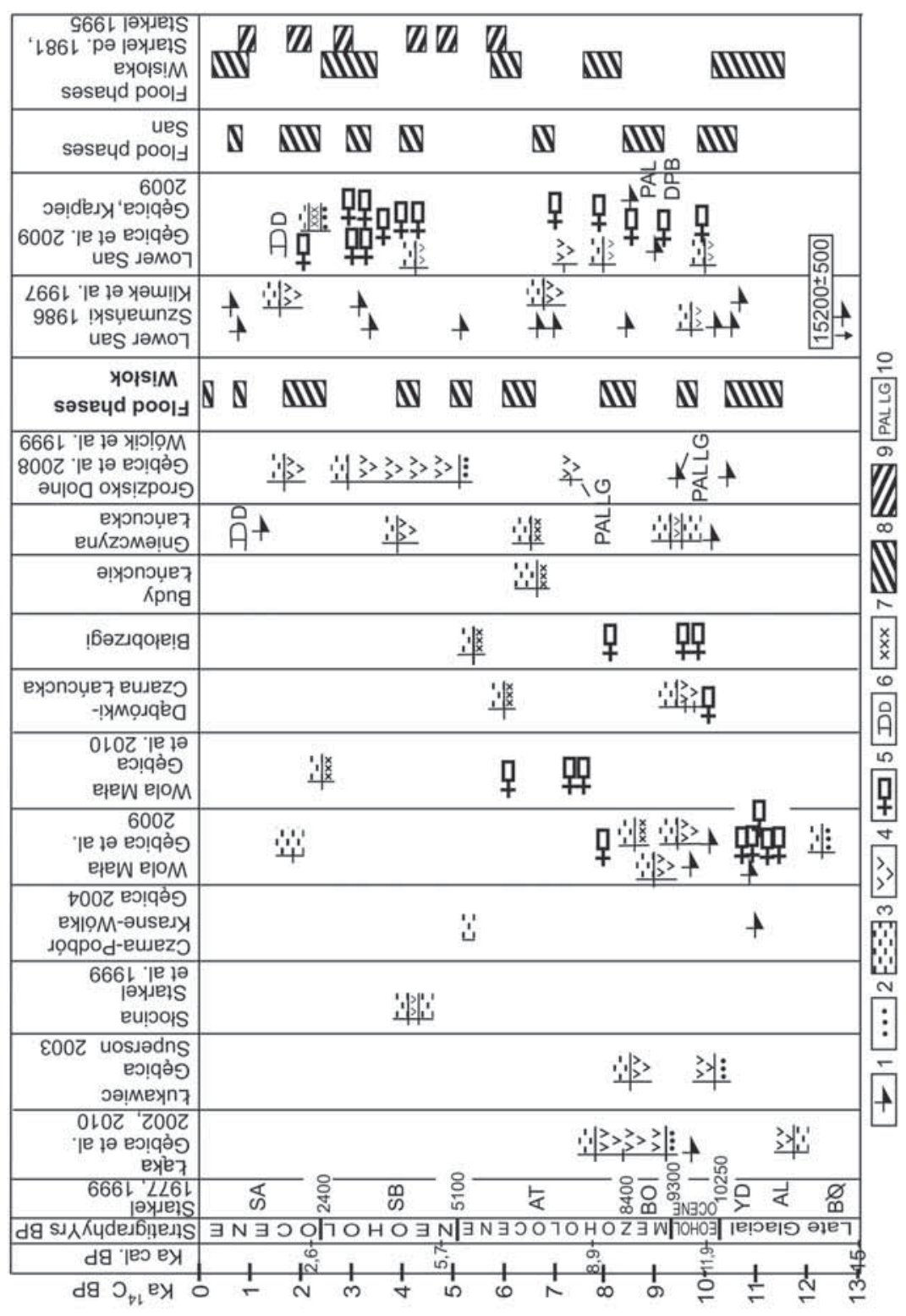

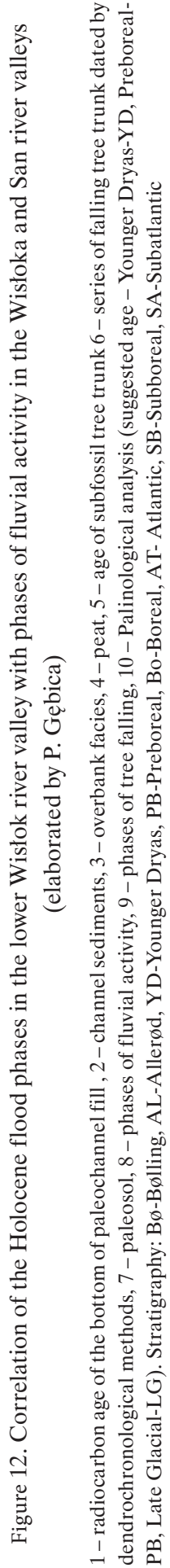


Białobrzegi. Sandy channel bars with plant detritus, outcropped in the gravel pit in Wola Mała village and dated to $9,800 \mathrm{BP}$, represent the same period. In the Boreal Phase, deposition of organic material prevailed in cut-off channels $(9,200-9,000 \mathrm{BP}$ at Wola Mała, 9,200 BP at Łąka, and 9,190 BP - palaeochannel bottom at Wawry on the San River) (Gębica et al., 2009a, b, 2010). The break of deposition of overbank clayey sediments in the Boreal Phase is recorded by a palaeosol dated at Wola Mała to 8,8008,700 BP (Gębica et al., 2009a).

The Early Holocene stabilization of the Wisłok riverbed, connected with peat accumulation in the floodplain, was stopped with the increase of flood frequency generating deposition of overbank and channel sediments at the beginning of the Atlantic Phase $(8,500-7,800 \mathrm{BP})$. This phase was recorded for the first time at Podgrodzie on the Wisłoka River (Starkel, 1977; Starkel ed., 1981). In the Wisłok River valley at Łukawiec, the peat layer below flood alluvium was dated to 8,500 $\pm 100 \mathrm{BP}$ (Gębica and Superson, 2003). However, the best evidence of this phase is preserved at the Wola Mała site, where channel sands with trunk dated at $8,010 \mathrm{BP}$ overlay a peat layer attributed to the Boreal Phase. The similar flood event took place in the depositional sequence at Białobrzegi (trunk dated at 8,100 BP). Exactly in the same period, deposition of silts within the cut-off channel of the San River at Kostków $(8,100 \pm 90 \mathrm{BP})$ took place (Gębica et al., 2009b). In this period, a 0.5-m-thick sand-silty layer was deposited in the peatbog in Tarnawa in the upper San River valley between 8,370 \pm 100 and 7,840 \pm 100 BP (Ralska-Jasiewiczowa, 1980).

This phase, which declined about 7,800$7,700 \mathrm{BP}$, was followed by a period of stabilization of river activity lasting till about 6,600 BP (according to Starkel, 2001). During this period flood, however, events in the Wisłok River valley took place, what is proved by the presence of two tree trunks buried in channel sands of the Wola Mała site, dated to 7,470 and 7,430 BP, as well as by deposition of flood clays upon the peat layer, dated at Łąka to 7,810 BP (Gębica et al., 2010). Redeposited tree trunks found at the Ostrów site on the San River and dated to 7,340 and 7,160 BP (Gębica and Krąpiec, 2009), and silty-peat deposits infilling the San palaeochannel near Stubno, dated to 6,900 BP (Klimek et al., 1997), represent the same period.

The beginning of burial of the palaeosol horizons by clayey-silty overbank sediments at Gniewczyna Łańcucka and Budy Łańcuckie, dated at $6,600 \mathrm{BP}$, was connected with the next phase of flood intensity within the period of 6,600-6,000 BP (Starkel, 2001). The palaeosol at Budy Łańcuckie contains cereal pollen, indicating deforestation of the floodplain and the Early Neolitic agriculture (Czopek and Podgórska-Czopek, 1995). At Wola Mała, the end of the active flood phase is marked by the tree trunk dated to 6,130 BP at a depth of $2.10 \mathrm{~m}$ (Gębica et al., 2010).

Around 5,400 BP, the sediments of crevasse splays were deposited in the palaeochannel at Czarna-Podbór (Gębica, 2004). The change in deposition from silts to organic sediments within the sequence of the Wisłok cut-off channel at Grodzisko Dolne took place about 5,200 BP. The end of organic accumulation in this sequence, about 3,000 BP, was connected with covering of the peat layer by flood sediments in the Atlantic Phase. The clay sediments (dated at the bottom to $4,000 \mathrm{BP}$ ) overlay the Preboreal peat in the Gniewczyna Łańcucka sequence. The overflows limited to the Słocina alluvial fan (Wisłok tributary in Rzeszów town), are proved by intercalations of gravels with wood fragments within the silt series, which were dated to 4,370 \pm 120 and 4,160 $\pm 240 \mathrm{BP}$ (Starkel et al., 1999). Exactly in the same time (4,370 BP), in the San River palaeochannel at Wawry, deposition of silts upon organic sediments is recorded (Gębica et al., 2009b). The flood phase 4,400-3,900 BP is represented by several redeposited trunks at Wysocko and Ostrów on the San River (Gębica and Krapiec, 2009). The series of channel alluvia with tree trunks at the Ostrów site, deposited within the 3,300-3,100 BP time 
span (Gębica and Krąpiec, 2009), confirms the phase of frequent floods during 3,5003,000 BP recorded in the Vistula River valley near Kraków (Kalicki, 1996; Kalicki and Krąpiec, 1996).

The sandy alluvia forming the natural levee of the Stary Wisłok at Wola Mała as well as sands deposited 1,780 BP upon the peat layer at Grodzisko Dolne are attributed to the Roman Period (2-4 th centuries AD) (Gębica et al., 2008, 2009a) (Figs. 11, 12). The alluvial series with tree trunks processed by people at the Radymno site on the San River was also deposited in the Roman Period (3-4 ${ }^{\text {th }}$ centuries AD) (Gębica and Krąpiec, 2009). The Mediaeval deposition is recorded by palaeochannel alluvial fill dated to 1,200-1,100 BP, within the 4-5 m high terrace at Gniewczyna Łańcucka. The younger generation of trunks was buried in channel bars from the end of the $11^{\text {th }}$ century till the beginning of the $13^{\text {th }}$ century (Gębica and Krąpiec, in print). These trees felled in a very short time span (shorter than 100 years), just in the period of floodplain stabilization observed in the Vistula River valley in the vicinity of Kraków (Kalicki and Krąpiec, 1996). The Stary Wisłok oxbowlakes system was abandoned due to avulsion after the flood in the middle of the $18^{\text {th }}$ century (Strzelecka, 1958).

The periods of increased river activity documented in the Lower Wisłok River valley during the Late Vistulian and the Holocene (Fig. 12), dated to the AllerödYounger Dryas, 9,900-9,600 BP, 8,5008,000 BP, 6,600-6,100 BP, 5,400-5,000 BP, 4,400-4,000 BP, 2100-1700 BP, as well as $11-13^{\text {th }}$ centuries $\mathrm{AD}$ and the middle of the $18^{\text {th }}$ century AD, are in full accordance with the phases evidenced earlier within the Upper Vistula River drainage basin (Starkel et al., 1996; Starkel 2001), particularly in the fore-mountainous section of the Wisłoka River valley (Starkel ed., 1981; Starkel, 1995), the Vistula River valley downstream of Kraków (Kalicki, 1991, 1996), as well as in the Lower San River valley (Szumański, 1986; Gębica et al., 2009b; Gębica and Krąpiec, 2009).

\section{ACKNOWLEDGEMENTS}

The research in 2006-2009 was performed within the framework of the project granted by the Polish Committee for Scientific Research (KBN) no 2P04E027 29: "Stratigraphy of alluvia and phases of the Holocene floods within the drainage basins of the San River and the upper Dnister River (based on the sedimentological, dendrochronological and radiocarbon methods)". The author would like to thank Dr. N. Kalinovyč from the Lviv State Ivan Franko University and Prof. K. Szczepanek from the Institute of Botany of the Jagiellonian University in Kraków for palynological analyses. Special thanks go to Prof. Anna Pazdur from the Radiocarbon Laboratory of the Silesian University of Technology in Gliwice, Dr. Nikolay Kovalyukh from the Radiocarbon Laboratory of the Ukrainian Academy of Sciences in Kiev, and Prof. Marek Krąpiec from the Laboratory of Absolute Dating for radiocarbon datings. The author would also like to thank MSc. Dominik Płoskonka from the Department of Geomorphology and Hydrology of Mountains and Uplands, Institute of Geography and Spatial Organization, Polish Academy of Sciences in Kraków, for grain size analyses. Prof. Sylwester Czopek and Prof. Andrzej Pelisiak from the Institute of Archaeology of the Rzeszów University and the Foundation of Rzeszów Archaeological Center are acknowledged for their help and financial support of sedimentological and radiocarbon analyses of samples taken from archaeological sites. The graphic preparation of some figures was performed by MSc. Dariusz Niemasik and student Paulina Kalandyk from Rzeszów, while translation into English was done by Dr. Jan Urban from the Institute of Nature Conservation, Polish Academy of Sciences in Kraków.

\section{REFERENCES}

Czopek, S. (2007), Grodzisko Dolne, stanowisko 22 - wielokulturowe stanowisko nad dolnym Wistokiem. Część I, od epoki kamienia do 
wczesnej epoki żelaza [Grodzisko Dolne, site no. 22 - multicultural site on the lower Wisłok river. Part I, from Stone Age to the Early Iron Age], Mitel, Rzeszów, 1-240.

Czopek, S. and Kadrow, S. (1987), Osada kultury pucharów lejkowatych w Białobrzegach, stan. 5, woj. Rzeszów [The settlement of the Funnel Beaker Culture in the Białobrzegi, site no. 5, Rzeszów voivodship], Sprawozdania Archeologiczne, 39: 73-88.

Czopek, S. and Podgórska-Czopek, J. (1995), Osadnictwo pradziejowe $w$ dolinie dolnego Wistoka [Prehistoric settlement in the lower Wisłok valley], in Ruszel, K. (ed.), Wistok. Rola rzeki $w$ krajobrazie naturalnym i kulturowym regionu [The Wisłok River. Role of the river in natural and cultural landscape], Rzeszów, 27-54.

Folk, R.L. and Ward ,W.C. (1957), Brazos river bar: a study of significance of grain size parameters, Journal of Sedimentary Petrology, 27: 3-26.

Friedberg, W. (1903), Atlas Geologiczny Galicyi. Tekst do zeszytu 16. Arkusze: Rzeszów i Łańcut [Geological Map of Galicia. Text to the fascicle 16. Rzeszów and Łańcut sheets], Wydawnictwo Komisyi Fizjograficznej Akademii Umiejętności, Kraków, 1-147.

Gębica, P., Bluszcz, A., Pazdur, A. and Szczepanek, K. (2002), Chronostratigraphy of Late Pleistocene fluvial deposits in the Wisłok river valley between Rzeszów and Łańcut, South Poland, Geochronometria, 21: 119-128.

Gębica, P. and Superson, J. (2003), Vistulian and Holocene evolution of the Wisłok river in the northern margin of the Sub-Carpathian Trough, in Kotarba, A. (ed.), Holocene and Late Vistulian Paleogeography and Paleohydrology, Prace Geograficzne 189, Instytut Geografii i Przestrzennego Zagospodarowania (IGiPZ) PAN, 209-223.

Gębica, P. (2004), Przebieg akumulacji rzecznej w górnym vistulianie w Kotlinie Sandomierskiej [The course of fluvial accumulation during the Upper Vistulian in Sandomierz Basin], Prace Geograficzne 193, Instytut Geografii i Przestrzennego Zagospodarowania (IGiPZ) PAN, 1-229.

Gębica, P., Czopek, S. and Szczepanek, K. (2008), Changes of climate and prehistoric settlement recorded in deposits of Wisłok paleochan- nel in Grodzisko Dolne, Sandomierz Basin, Sprawozdania Archeologiczne, 60: 295-323.

Gębica, P., Dryniak, Ł., Okoński, J., Zych, R., Hozer, M., Bajda-Wesołowska, A., Wilk, M., Niemasik, D. and Pasterkiewicz, W. (2010), Badania geoarcheologiczne na trasie autostrady A-4. Stratygrafia nawarstwień i zmiany środowiska na stanowiskach w Łące, Woli Małej, Białobrzegach, Gorliczynie i Ożańsku, woj. podkarpackie [Geoarcheological research on the route of the motorway A4. The stratigraphy of the layers and changes of the environment on the sites in Łąka, Wola Mała, Białobrzegi, Gorliczyna and Ożańsk, Podkarpackie voivodship], Materiaty i Sprawozdania Rzeszowskiego Ośrodka Archeologicznego, Instytut Archeologii Uniwersytetu Rzeszowskiego, 31: 79-86.

Gębica, P. and Krąpiec, M. (2009), Young Holocene alluvia and dendrochronology of subfossil trunks in the San river valley, Studia Geomorphologica Carpatho-Balcanica, 43: 63-75.

Gębica, P. and Krąpiec M. (in print), Young Holocene alluvia and dendrochronology of subfossil trunks in the Wisłok valley near Przeworsk, Geochronometria.

Gębica, P. and Mitura, P. (2005), Wstępne wyniki badań geomorfologiczno-archeologicznych przeprowadzonych na stanowisku $\mathrm{nr} 4 \mathrm{w}$ Terliczce k. Rzeszowa [Preliminary results of the geomorphological-archeological studies conducted in the Terliczka archeological site no. 4 near Rzeszów], in Archeologia Kotliny Sandomierskiej, Rocznik Muzeum Regionalnego w Stalowej Woli, 4: 19-38.

Gębica, P., Płoskonka, D. and Kalinovyč, N. (2009a), Origin, lithology and age of the Holocene terrace of the Wisłok river in the Sandomierz Basin, Studia Geomorphologica Carpatho-Balcanica, 43: 77-95.

Gębica, P., Wieczorek, D. and Szczepanek, K. (2009b), Late Vistulian alluvial filling in the San river valley in the Carpathian foreland (north of Jarosław town), Studia Geomorphologica Carpatho-Balcanica, 43: 39-61.

Kalicki, T. (1991), The evolution of the Vistula river valley between Cracow and Niepołomice in Late Vistulian and Holocene times, in Starkel, L. (ed.), Evolution of the Vistula river valley during the last 15000 years, part 4, Geographical Studies, Special Issue, Instytut 
Geografii i Przestrzennego Zagospodarowania (IGiPZ) PAN, 6: 11-37.

Kalicki, T. (1996), Phases of increased river activity during the last 3500 years, in Starkel, L. (ed.), Evolution of the Vistula river valley during the last 15000 years, part 6, Geographical Studies, Special Issue, Instytut Geografii i Przestrzennego Zagospodarowania (IGiPZ) PAN, 9: 94-101.

Kalicki, T. and Krąpiec, M. (1996), Reconstruction of phases of the ,black oak" accumulation and flood phases, in Starkel, L. (ed.), Evolution of the Vistula river valley during the last 15000 years, part 6, Geographical Studies, Special Issue, Instytut Geografii i Przestrzennego Zagospodarowania (IGiPZ) PAN, 9: 78-85.

Klimek, K., Łanczont, M. and Bałaga, K. (1997), Późnovistuliańskie i holoceńskie wypełnienie paleomeandra w dolinie Sanu koło Stubna [LateVistulian and the Holocene infilling of the paleomeander in the San river valley near Stubno], in Łanczont, M. (ed.), Glacjat i peryglacjat Kotliny Sandomierskiej i Przedgórza Karpat [Glacial and periglacial of the Sandomierz Valley and the Carpathian Foreland], UMCS, Lublin, 60-71.

Lewakowski, J. (1935), Mapa terenów powodzi lipcowej w 1934 r. [The map of flooded areas during the July 1934], Wiadomości Stużby Geograficznej, 9: 288-294.

Ludera, F. (1930), Flora dyluwialna okolic Rzeszowa $i$ Łańcuta [Diluvium vegetation in the vicinity of Rzeszów and Łańcut], archival report, the Institute of Botany, the Jagiellonian University, Kraków.

Ralska-Jasiewiczowa, M. (1980), Late Glacial and Holocene vegetation of the Bieszczady Mts. (Polish Eastern Carpathians), Acta Palaeobotanica, 20: 1-202.

Starkel, L. (1958), Stratigraphy of Holocene Deposits in the Carpathian Foreland, Bulletin de l'Academie Polonaise des Sciences, serie des sciences chimiques-géologiquesgéographiques, 6: 395-398.

Starkel, L. (1960), Rozwój rzeźby Karpat fliszowych w holocenie [Development of relief of the Flysch Carpathians during the Holocene], Prace Geograficzne 22, Instytutu Geografii (IGiPZ) PAN, 1-239.

Starkel, L. (1972), Kotlina Sandomierska [Sandomierz Basin], in Klimaszewski, M. (ed.),
Geomorfologia Polski [Geomorphology of Poland], vol. 1, Wydawnictwo Naukowe PWN, Warszawa, 138-166.

Starkel, L. (1977), Paleogeografia holocenu [Palaeogeography of the Holocene], Wydawnictwo Naukowe PWN, Warszawa.

Starkel, L. (1995), New data on the Late Vistulian and Holocene evolution of the Wisłoka valley near Debica, in Starkel, L. (ed.), Evolution of the Vistula river valley during the last 15000 years, part 5, Geographical Studies, Special Issue, Instytut Geografii i Przestrzennego Zagospodarowania (IGiPZ) PAN, 8:73-90.

Starkel, L. (2001), Historia doliny Wisły od ostatniego zlodowacenia do dziś [Evolution of the Vistula river valley since the Last Glaciation till the present), Monografie 2, Instytut Geografii i Przestrzennego Zagospodarowania (IGiPZ) PAN, 1-263.

Starkel, L. (2002), Younger Dryas - Preboreal transition documented in the fluvial environment of Polish rivers, Global and Planetary Change, 35: 157-167.

Starkel, L., ed. (1981), The evolution of the Wisłoka valley near Dębica during the Lateglacial and Holocene, Folia Quaternaria, 53: $1-91$.

Starkel, L. and Gębica, P. (1995), Evolution of river valleys in southern Poland during the Pleistocene-Holocene transition, Biuletyn Peryglacjalny, 34: 177-190.

Starkel, L. Gębica, P., Kalicki, T., Ludwikowska, M. and Niedziałkowska, E. (1999), Chronostratygrafia aluwiów $i$ form fluwialnych w potudniowej Polsce [Chronostratigraphy of alluvia and fluvial landforms in southern Poland], in Pazdur, A., Bluszcz, A., Stankowski, W. and Starkel, L. (eds.), Geochronologia górnego czwartorzęu Polski w świetle datowania radioweglowego $i$ luminescencyjnego [Geochronology of the Upper Quaternary of Poland in the light of radiocarbon and luminescence dating], Wind. Wojewoda J., Wrocław, 132-156.

Starkel, L. Kalicki, T., Krąpiec, M., Soja, R., Gębica, P. and Czyżowska, E. (1996), Hydrological changes of valley floors in upper Vistula basin during the last 15000 years, in Starkel, L. (ed), Evolution of the Vistula river valley during the last 15000 years, part 6 , 
Geographical Studies, Special Issue, Instytut Geografii i Przestrzennego Zagospodarowania (IGiPZ) PAN, 9: 1-128.

Strzelecka, L. (1958), Historyczna dokumentacja niektórych młodszych zmian hydrograficznych na brzegu Karpat [Historical documentation of some younger hydrographical changes on the margin of Carpathians], $\mathrm{Cza}$ sopismo Geograficzne, 29 (4):455-472.

Szumański A., (1983), Paleochannels of large meanders in the river valleys of the Polish Lowland, Quaternary Studies in Poland, 4: 207-216.

Szumański, A. (1986), Postglacjalna ewolucja i mechanizm transformacji dna doliny dolnego Sanu [Postglacial evolution and mechanizm of transformation of the lower San valley floor], Kwartalnik AGH, Geologia, 12 (1):1-84.

Wójcik, A., Malata, T. and Szczepanek, K. (1999), Stanowisko Grodzisko Nowe. Problem wieku plejstoceńskich teras piaszczystych $w$ dolinie Sanu przy ujściu Wistoka [Site Grodzisko Nowe. The problem of age of the Pleistocene sandy terraces in the San valley at the mouth of Wisłok river], in VI Konferencja stratygrafii plejstocenu Polski „Czwartorzęd wschodniej części Kotliny Sandomierskiej”, Czudec, 31 VIII-3 IX 1999 [6th Stratigraphy of Poland's Pleistocene Conference "The Qouternary of the eastern part of the Sandomierz Basin], Państwowy Instytut Geologiczny, Kraków, 88-89.

Wójcik, A. and Malata, T. (2004), Objaśnienia do Szczegótowej mapy geologicznej Polski 1:50000, arkusz Jarostaw [Explanations to the Detailed geological map of Poland 1:50,000, Jarosław sheet], Państwowy Instytut Geologiczny, Warszawa, 1-45.

Paper first received: May 2011

In final form: August 2011 